\title{
Compassionate pedagogy: the ethics of care in early childhood professionalism
}

Article

Accepted Version

Taggart, G. (2016) Compassionate pedagogy: the ethics of care in early childhood professionalism. European Early Childhood Education Research Journal, 24 (2). pp. 173-185. ISSN 1752-1807 doi:

https://doi.org/10.1080/1350293X.2014.970847 Available at https://centaur.reading.ac.uk/38539/

It is advisable to refer to the publisher's version if you intend to cite from the work. See Guidance on citing.

To link to this article DOI: http://dx.doi.org/10.1080/1350293X.2014.970847

Publisher: Taylor and Francis

All outputs in CentAUR are protected by Intellectual Property Rights law, including copyright law. Copyright and IPR is retained by the creators or other copyright holders. Terms and conditions for use of this material are defined in the End User Agreement.

\section{www.reading.ac.uk/centaur}

\section{CentAUR}

Central Archive at the University of Reading 
Reading's research outputs online 
Geoff Taggart @

Dr Geoff Taggart

g.taggart@reading.ac.uk

01183782643

Institute of Education

University of Reading

Redlands Rd

Reading

BERKS

RG1 5EX 
Geoff Taggart (C)

\section{Compassionate pedagogy: the Ethics of Care in Early Childhood Professionalism}

\section{Abstract}

This paper builds upon an earlier attempt (Taggart, 2011) to articulate a rationale for professional training in early childhood education and care (ECEC) which is ethical as opposed to one which is purely instrumental or rooted in a patriarchal notion of women's supposed unique suitability. The argument proposes that a feminist approach to ethics, as both socially critical and psychologically affective or flexible, has a particular relevance to professional identity in ECEC. In particular, compassion, as a concept which has both sociological and psychological connotations, foregrounds the ethical dimension of the work whilst overcoming false dichotomies between discourses of 'children's rights' and 'care'. The implications for the training and professional identity of practitioners are discussed.

Le présent article approfondit une précédente tentative (Taggart, 2011) de structuration des fondements d'une formation professionnelle dans le domaine de l'éducation et des soins apportés à la petite enfance (ECEC en anglais) qui soit éthique à l'opposé d'une formation qui soit purement fonctionnelle ou fondée sur la notion patriarcale de capacités exclusives de prise en charge par les femmes. Les thèses suggèrent qu'une notion féministe de conscience, étant à la fois socialement capables et psychologiquement perméables ou flexibles, a une importance particulière comme modèle pour une identité professionnelle dans le domaine de I'ECEC. La compassion, en tant que concept ayant des connotations à la fois sociologiques et psychologiques, en particulier, met en exergue la dimension éthique de l'étude tout en allant outre les fausses dichotomies entre les discours concernant les « droits des enfants" et « la prise en charge ». Les implications pour la formation et l'identité professionnelle des praticiens sont étudiées. 
Geoff Taggart @

Dieses Dokument stützt sich auf einen früheren Versuch (Taggart, 2011), Grundüberlegungen für die berufliche Fortbildung in den Bereichen frühkindliche Betreuung, Bildung und Erziehung (ECEC, Early Childhood Education and Care) auszudrücken, welche im Gegensatz zu dem Ansatz, der rein instrumental oder in der patriarchalen Vorstellung, dass nur Frauen fähig sind, die Erziehung zu übernehmen, ethisch begründet sind. Es wird vorgeschlagen, dass eine feministische Vorstellung von Bewusstsein, sowohl gemeinschaftsfähig und psychologisch durchdringbar als auch flexibel, als Modell eine besondere Relevanz für die berufliche Identität in frühkindlicher Betreuung, Bildung und Erziehung hat. Insbesondere Mitgefühl stellt als Konzept mit sowohl soziologischen als auch psychologischen Auswirkungen die ethische Dimension der Arbeit in den Vordergrund, während falsche Dichotomien zwischen Diskursen der „Kinderrechte“ und „Erziehung“ überwunden werden. Diskutiert werden die Implikationen für die Ausbildung und berufliche Identität von Berufsausübenden.

El presente artículo se basa en un intento previo (Taggart, 2001) de establecer un sistema de capacitación profesional para la educación infantil y atención a la infancia (ECEC, por sus siglas en inglés) que sea ético en lugar de puramente instrumental o producto de la noción patriarcal sobre la supuesta capacidad inherente de la mujer para cuidar de los niños. Proponemos que una noción feminista de la consciencia, que sea tanto socialmente funcional como psicológicamente permeable y flexible, es de especial relevancia en la construcción de modelos de identidad profesional en la educación infantil (ECEC). En particular, la compasión, como concepto de connotaciones tanto sociológicas como psicológicas, coloca en un primer plano la dimensión ética del trabajo a la vez que supera falsas dicotomías entre los discursos sobre los "derechos del niño" y el "cuidado de los niños". Se analizan las implicaciones de ello para la capacitación y la identidad profesional de los especialistas. 
Geoff Taggart (C)

\section{Introduction}

In recent times, it has become clear that two competing approaches seek to determine the purpose of ECEC, a discourse of care and a discourse of rights. Each discourse effectively constructs its own model of the young child, the most appropriate form of provision and suggests the direction which training of practitioners should take. Firstly, the modernist discourse of care centres on the potentially vulnerable child and upholds the ideal of the substitute mother as the means by which women may be freed to enter the labour market. Secondly, a more recent postmodernist discourse of children's rights advances an image of the capable 'child-citizen' and seeks to establish nurseries as democratic spaces where genuine dialogue can occur: here the model of the professional is that of social pedagogue/activist. Up to now both orientations have been presented as mutually exclusive. In order to overcome this dichotomy, this paper draws on feminist ethics to argue that the comprehensive model of human (i.e. child) agency it presents, as simultaneously critical and vulnerable, may be of value to ECEC. It can also be described as representing a compassionate outlook. Compassion is simultaneously at the heart of social justice campaigns which seek to enhance the capabilities of oppressed groups and also at the heart of psychological understandings about the origins of the capacity to care. The argument is that a '360-degree' compassionate pedagogy will therefore seek to nurture children who are vocal, capable citizens as well as being secure, well-adjusted people.

\section{Competing discourses in ECEC}

In the context of ECEC, the discourse of care has a longer history than the discourse of rights. In post-war England, Bowlby's identification of disorders resulting from insecure attachments to caregivers was seen as ground-breaking (e.g. Bowlby, 1958). That remote parenting might produce emotionally 'avoidant' children and erratic parenting produce ambivalent or 'preoccupied' children seem unremarkable notions today. However, these insights proved to 
Geoff Taggart (C)

be extremely valuable, particularly in changing attitudes towards children's admission to hospital (Robertson and Robertson, 1989). In the intervening years, reducing such trauma and making daycare settings as home-like as possible became such commonplace aims that the negative implications of this care-based practice have only recently been explored. For example, creating settings that attempt to reproduce the home environment announces from the outset that the work of a practitioner is to replicate the child/mother relationship as much as possible. An alternative view would be to see settings as 'fora' rather than as substitute homes, in which a network of inspiring, creative relationships is cultivated in the style of the inclusive, democratic Reggio Emilia pedagogy (Dahlberg et al, 2008). This competing, alternative perspective has recently taken hold to the extent that 'listening to the voice of children' is now a key element of good practice and signals the way in which practitioners are encouraged to conceive of their relationships with children in a more democratic way (Pascal and Bertram, 2009; Clark and Moss, 2011). In the same way that disabled people are understandably more interested in rights than sentiment, rights are often seen as a preferential focus within ECEC:

'... Instead, early childhood services offer another possibility : that young children might be viewed as active subjects with rights and voice, members of a social group and located both in the family and in the wider community.' (Moss, 2003:37)

Dahlberg et al (2008) offer 'intensity of relationship' as an alternative to the language of care. Each of these perspectives reveal weaknesses in the other. For example, the rights discourse does not provide a psychological account of the means by which this intensity can be fostered in a supportive way. It cannot explain moral motivation in relational contexts. A mother or practitioner, it would seem, may recognise a child's right to play but she does not play with him solely out of respect for Kant's categorical imperative: she acts from an ethic of care (Taggart, 2011). In this sense, Bowlby's insights into the emotional nature of attachment 
Geoff Taggart @

relationships cannot be dismissed so easily. Whilst the analyses of Dahlberg et al (2008) are vital in challenging uncritical approaches to gender and childcare, they remain strongly sociological rather than psychological, and therefore do not address with sufficient subtlety the emotional nature of the relationships at the heart of the 'forum'. Sociologists, notoriously ambivalent about individual emotions, rarely write about love except as the epiphenomena of social processes and so do not seem to grant any sense of reality to the strength of feeling between an adult and child. At the same time, it must be acknowledged that a sociological, postmodernist stance (e.g. Burman, 2007) has usefully exposed the ways in which twentieth century attachment theory had the effect of reinforcing gender stereotypes. After the demonstrations of mass female labour in the years 1939-45, the radio broadcasts of Winnicott, for example, legitimised the return to prewar attitudes towards women working outside the home.

These two positions bring with them opposing epistemological frameworks, as represented by their intellectual traditions. In psychology, understanding of the world occurs affectively as much as it does cognitively, through enlarging self-awareness and developing authenticity in relations. For sociologists, this view seems realist and naïve. For them, human agency is profoundly conditioned by social and political forces and so genuine understanding of the world occurs through inquiry into its political realities. The argument of this paper is that an epistemology which is psycho-social and which attributes significance both to feeling and to critical enquiry can fuel an ethical pedagogy which attends to both the emotional quality of relationships and also to social justice.

\section{Feminist care ethics and the moral subject}

Care ethics (e.g. Noddings, 1984) can be seen as indebted to two parallel strands in feminist thought, a focus on highlighting the 'invisible' work of women and a re-appraisal of emotion in intellectual life. Since the dawn of Western feminism, it has been typified by a critical attitude 
Geoff Taggart (C)

towards normative social attitudes, particularly those which conceal and marginalise the vital work of care carried out by women (e.g. Oakley, 1974), such as the domestic labour of housework and raising children. This critique underpins the ethic of care articulated by Held (2007:15) which opposes the liberal tradition of autonomous individuals:

'The liberal view overlooks the facts that citizens have all been helpless in infancy, totally dependent on others for years of affectionate care, and that those who have cared for them have often been dependent on still others for support while their labour was expended in such care' (Held, 2007: 15)

This invisible and largely unrewarded provision of care has been exposed and articulated as part of an intention to empower women and attempts to bring care into the political arena (e.g Tronto,1993 ;Sevenhuisjen, 2004) can be seen as an extension of this earlier work.

At the same time as seeking to expose political realities, care ethics also calls upon us to be responsive, affective and flexible in particular ethical situations. Indeed, the ideal carer exhibits 'engrossment' in the phenomenological encounter with the 'cared-for' while experiencing 'motivational displacement' which temporarily marginalises the carers' own concerns (Noddings, 1984). This attention to the moral emotions of care rests upon a longstanding concern within feminist epistemology to critique the dominance of 'masculine' ways of understanding the world through detachment and propositional logic (e.g. Roland, 1981). In its place, such writers propose instead a more holistic way of understanding our environment and making sense of ethical dilemmas, one that acknowledges the importance of intuitions and motivations in prompting and sustaining our concerns.

Care ethics therefore contains a model of consciousness which is simultaneously critical and affective, which is willing to question socio-political reality whilst engaging the heart as well as the head. This model of the self has recently been advanced within 'psycho-social' studies in 
Geoff Taggart (C)

adjacent fields, exploring young feminine identities (Walkerdine et al, 2001), the motivations of those in caring professions (Hoggett et al, 2006) and also in research into the Tavistock tradition of infant observation (e.g. Hollway and Froggett, 2012). However, it is debatable whether care ethics, and the holistic epistemology which underpins it, has been applied to thinking about the work of early childhood practitioners.

\section{Introducing compassion}

The remainder of this paper argues that, because of the 'psycho-social' connotations of compassion, it serves as an ideal way to conceptualise the care ethical approach and to provide a platform for training in ECEC.

Human activities which would be described as compassionate are those which seek to alleviate suffering, vulnerability or inequality in a public sphere whilst also calling upon distinct personal emotions for their motivation. In psychology, advances in brain-imaging and in understanding of hormones such as oxytocin have recently attracted researchers to study compassion (e.g.Simon-Thomas, 2012; Rockliff, 2012). Compassion has been explained as part of the evolutionary 'affiliative system' which is suppressed through shame and guilt and can be cultivated therapeutically (e.g. Gilbert, 2009).

From the perspective of social theory, a key historical influence on compassionate politics can be found in figures of the humanistic Freudian Left (e.g. Brown,1959; Marcuse, 1965; Fromm, 1959) whose alternatives to bureaucratic capitalism centred around the celebratory notion of 'eros'. Their impact can be detected in the critical pedagogies and theologies to have emerged towards the end of the $20^{\text {th }}$ century, both of which champion compassion as a key principle of individual behaviour and social relations. For example, Purpel (1989:117), strongly influenced by the work of Paulo Freire, highlights the way in which compassion is lost once a school exchanges its role as community centre with that of exam factory. He calls for the 'cultivation, 
Geoff Taggart (C)

nourishment and development of a cultural mythos that builds on a faith in the human capacity to participate in the creation of a world of justice, compassion, caring, love and joy.' The inclusive spirituality of Fox (1999: 24) also places compassion centre stage:

'Compassion, being so closely allied with justice-making, requires a critical consciousness, one that resists all kinds of 'keptnesses'... It implies a going out in search of authentic problems and workable solutions, born of deeper and deeper questions.'

Of particular relevance to ECEC is the focus within such discourse on the restoration and celebration of 'eros', the play and collaboration which are central to the building of community and solidarity. Law and Martens (2012), for example, describe the ways in which radical change movements rely upon a co-operative style of childcare which symbolises their compassionate politics. For the childcare worker, therefore, compassion may describe both psychological reality and political vision.

Hopefully, I am making my case that professional work in ECEC is a compassionate practice and, as such, accommodates both the discourses of care and of rights, since compassion 'involves all our faculties and facilities comprising mind-body-heart-spirit (and whatever else is part of this ontological package called human being)' (Bai, 2014:4). Although a holistic notion, compassion will now be analysed separately in social and psychological terms, simply for the purposes of clarity, to gauge its relevance to the sector.

\section{Compassion and attachment}

In the field of psychology, compassion would seem to be an outcome of, as well as a condition for, secure attachment. For example, secure mothers are more affectionate with their children when they return after a brief separation (Crowell and Feldman, 1991). As adults, secure individuals are more responsive to the needs of romantic partners (Kunce and Shaver, 1994) 
Geoff Taggart (C)

and more positive about caring for older relatives (Sorensen et al, 2002). Yet secure

attachment is also related to ethics more generally, being correlated with compassion, benevolence and humanitarianism (Mikulincer et al, 2003) and forgiveness (Burnette et al, 2007). The connection is spelt out clearly by Gillath et al (2005:9):

...'This ability to help others is a consequence of having witnessed and benefited from good caregiving on the part of one's own attachment figures, which promotes the sense of security as a resource and provides models of good caregiving.'

Compassionate practitioners would therefore seem to produce compassionate, securelyattached children. Unsurprisingly perhaps, secure attachments in adults are also associated with voluntary community work (Gillath et al, 2005) and with low levels of prejudice: even the act of priming research subjects with proximity-related words such as 'love', 'hug' or 'close' can make them more likely to interact with perceived outsiders and be less discriminatory towards them (Mikulincer and Shaver, 2001). This association between compassion and secure attachment is further supported by data indicating that, in traumatic situations, the latter can mitigate the effects of 'compassion fatigue' (Tosone et al, 2010). According to Narvaez (2008), the attachment system is primarily responsible for one of the three ethical instincts developed by human evolution and development, that of 'engagement'. For Noddings (2012), it is the 'incubator' of adult moral life. Indeed, for Mikulincer and Shaver (2005), the evidence is so great that, drawing on humanistic psychology (e.g. Rogers 1961), they go so far as to suggest that secure attachment is the basis for a benevolent, growth-oriented approach to life in which a lack of defensiveness and openness to vulnerability in oneself and others makes caretaking of all kinds possible. In a specific ECEC context, this influence can be seen in Johnson's (2010:5) use of Rogers' terms to propose that the ideal practitioner embodies authenticity and extends 'unconditional positive regard' to the child. She alludes to the importance of secure 
Geoff Taggart (C)

attachments in commenting that this encounter 'brings its own demands on the individual and may only be possible, at times, when there is respect for oneself as well as for the other.'

The growing evidence for the implications of evolutionary care-seeking and care-taking in consistently compassionate behaviour should encourage us to broaden the scope of compassion beyond suffering and its stereotypical association with nuns and nurses attending to the diseased and dying. Compassion is at once both more ordinary and fundamental. From an evolutionary perspective, compassion emerged because it enhances the welfare of vulnerable offspring who are born more prematurely than any other mammal and who required a degree of care unparalleled elsewhere in nature if they are to reach maturity. Certainly, displays of compassion involving soothing touch and specific vocalisations have been observed in all human cultures and in many mammalian species. The strength and importance of compassion is shown in advances in neuroscience which demonstrate that human beings of all ages are to some extent 'hard-wired' to respond beneficially to it. The hormone oxytocin is stimulated in the giver by compassionate behaviour which decreases stress and benefits the immune and cardiovascular systems (Gilbert, 2011). Goetz et al (2010:354) conclude that 'within this vulnerable offspring perspective, compassion is the brief affective state associated with caregiving toward those who suffer or are in need.' This argument is clearly significant for ECEC since, by emphasising the role of compassion in addressing need or vulnerability in general rather than suffering specifically, it is extended to include the work of early childhood practitioners. This extension is not so unnatural if one remembers the etymological roots of 'compassion' itself which, in Semitic languages, are close to that of the word for 'womb' (Armstrong, 2011): the emphasis is on holding and containment of the vulnerable.

\section{Thinking sociologically: compassion rather than 'customer care'}

By highlighting the ethical nature of the practice, reframing 'childcare' as compassionate work with children places this endeavour alongside other overtly compassionate professions such as 
Geoff Taggart (C)

nursing, social work, counselling and ministry. The traditional notion of a profession, after all, is of a service which promotes human flourishing by combatting social evils: teachers address ignorance, doctors address disease and lawyers address injustice (Carr, 1999) In this light, the professional mandate of early years practitioners is to water the seed of human flourishing itself and foster compassion in future society by promoting and maintaining secure attachments. We can now examine social and occupational change more closely, particularly in professions, to show why ECEC should also aspire to this status and why it represents compassionate professionalism, not simply a form of low-skilled customer care.

The effect of postmodern economies has been to make the traditional professions exhaustively accountable whilst extending the adjective 'professional' to virtually all occupations. Because of its vague definition, Fournier (1999), drawing upon Rose's (1999) insight into the 'government of the soul', argues that the injunction to 'be professional' now functions as a mechanism of disciplinary control over subjective life. In contemporary management, companies commonly seek to engage employees' values, attitudes, emotions and capacity to care: the intention may be for employees not just to smile as if they care but to 'smile and mean it' (Sturdy, 1998: 29). Certainly, within ECEC, managerial control of dress, deportment and speech is increasingly justified on the grounds of 'professionalism', coinciding with the sevenfold increase in corporate childcare between 1997 and 2007 (Penn, 2007). Care is one of these dispositions. Practitioners share a duty with most public-facing work environments that they will be seen to care: for example, the US Bright Horizons chain has 'heart principles' which are displayed in every setting and which employees are meant to embody. Boyer et al (2012) argue that the demands of emotional self-regulation in childcare workers are particularly high in the face of 'emotionally permeable or boundary-less' young children. The requirement for such 'deep acting' (Hochschild, 1986), coupled with minimal autonomy and notoriously low pay (Daycare Trust/TUC, 2008) invites a comparison between childcare work and another field of care work, the call centre industry. Callaghan and 
Geoff Taggart (C)

Thompson (2002), in their research into call centre training, contrast the affective qualities of enthusiasm, conviviality and "personality" sought by managers with the conformity which is ultimately required. Whilst the managers talked about the job requirements in terms of communication skills, the employees themselves associated the requirements with surviving stressful and repetitive work. In these senses, 'care' is a synonym for the internalisation of the customer-focussed ethic and the emotional attitude an employee is required to adopt is very similar whether the company slogan is 'we care for every step your child takes' or 'we care for your car as if it were our own'. It is easy to see how 'care' may come to be appropriated by multinational childcare chains and interpreted in a way that is different in a subtle sense from that used by the average childcare worker. However, once we recognise the key difference between these examples, that only the child is vulnerable in the way I have argued, it is clear that compassion is the more appropriate response, calling for an ethical professional rather than a worker skilled in emotional labour.

\section{Implications for training and CPD}

Compassionate pedagogy presents an image of the practitioner who, on the one hand, is politically astute and, on the other, flexible and dialogical. In this respect, she models for children the opportunity to be continuously vulnerable and open to others and, at the same time, powerfully capable of contributing. Enacting this vision requires giving attention to training and CPD of practitioners.

Students inevitably enter their training with a 'folk pedagogy', a bundle of attitudes and beliefs about the way in which adults and children work best together. Goldstein and Lake (2000:85) observe that ideas about caring feature strongly: 'phrases like 'second nature', 'a gift', 'completely instinctive' and 'natural talent' peppered all of the students' journals.' This 
Geoff Taggart (C)

assumption that care and compassion are rooted in instinct (the 'you've either got it or you haven't' theory) is rarely unpicked in the course of training. That they are related to the intellectual capacity for judgement is not explored. At the same time, to the extent that ethical development is addressed at all in trainings, this tends to focus on the cultivation of ethical reasoning and analysis (Newman and Pollnitz, 2001) and the affective dimension is marginalised. The contrary argument, that compassion is intelligent and learnable, is put by Gilbert (2009:432):

'Compassionate skills are things that we can practise and work on by deliberately making choices. We can learn to pay compassionate attention, to think compassionately, to engage in compassionate behaviour and practise compassionate feeling.'

Empirical evidence is beginning to support this skill-based perspective (Weng et al, 2013; Neff and Germer, 2013; Jazaieri et al, 2013). Once this evidence is acknowledged, and we recognise that 'ethical practice cannot be understood impersonally' (Hugman, 2005:50), then ethical training, involving compassion, must engage the emotions. In the words of Gerhardt (2010:205), supplying mere guidance about children's emotional development without experiential training 'is no more effective than giving someone a recipe book and expecting them to be a great cook.' By contrast, there are examples of training programmes which ask students to reflect analytically upon their own assumptions and experience of care. Video can be used sensitively (Elicker et al, 2008) in these cases. In their study, Swick and Brown (1999:116) affirm the benefits of 'bringing alive the voices of early childhood teacher education students in ways that validate their journey toward becoming caring persons'. Suggested questions for students include:

'What values and beliefs am I carrying into relationships with children, parents and other teachers? 
Geoff Taggart (C)

Who am I becoming as a person who will spend significant time with people who will be our future?'

Of course, these questions need a political context in order to be answered fully and this could be provided with reference to the compassionate politics of writers such as Purpel (1989) and Fox (1999) discussed above.

In recognising that the 'relational work' of ECEC is a form of ethical practice (Dalli and Cherrington, 2009), there are also implications for ongoing CPD, particularly in terms of highlighting the human tendency to turn compassion into pity. It is clear that, as care ethicists point out, care can easily become a parody of itself:

'The tendency to equate caring with a kind of overbearing attention, benevolent but smothering, is a distorted but widespread view of care. Care as a disposition often misleads people into thinking they are caring when they only have the correct motives of wanting to care, to help others, to be benevolent, and so on, however much the intention misinterprets the recipient's wishes...' (Held, 2007:55)

Left unexamined, our compassion does not tend to be expressed instinctively and indiscriminately but is intimately related to our socio-political reasoning (Nussbaum, 2001). For example, we will only feel compassionate towards people whom we feel do not deserve their suffering or vulnerability and are not responsible for it. We may also attempt to shield ourselves by offering pity instead of compassion, a tendency which disabled people often comment upon. Van Galen (1996) demonstrates that it is easy for teachers to believe that they are 'caring' even when their actions seem to more closely resemble pity and ultimately reinforce the status quo. The negative connotations of pity are revealed via a search on a lexicographical search engine (www.sketchengine.co.uk), which shows that, compared to compassion, pity alone is associated with the words 'scorn' and 'sorrow' and significantly more 
Geoff Taggart (C)

likely to be associated with 'disgust' and 'remorse'. The fact that pity, contrasted with compassion, may be 'contemptuous' or 'condescending' highlights the implicit power relation. From the point of view of compassionate pedagogy, it is therefore important that children and families are not treated by practitioners as if they are any more vulnerable, 'at risk' or 'hard to reach' than the practitioners themselves: for compassion to be inclusive, it has to be directed at oneself as well as others. Neff (2003) outlines a validated and reliable psychological concept of 'self-compassion', showing how it may be purposefully developed and how it may be more robust and achievable than self-esteem. In particular, the effects have been studied via interviews with nursing teachers (Gustin and Wagner, 2012) and social workers (Ying, 2009;Rickers, 2012):

"If you don't have it (self-compassion) good luck to you. And I don't know how you wouldn't burn out you know. And we've seen it in practice...just going from personal experience for me, if I'm giving myself permission to take care of myself then I think that I'm better at my work...Because there is a letting go that happens with selfcompassion and otherwise you're holding on to all the things you experience during the day.' (Rickers, 2012:87)

Whereas an attitude of pity implies that compassion is a personal attribute bestowed on a deserving individual, an attitude of genuine compassion arises from the acknowledgment that compassion is not a personal attribute at all but part of the cultural and spiritual space we inhabit and therefore as much available to ourselves as to others. Willingness to reflect is therefore essential. In the US, a model of 'reflective supervision' has been shown to assist practitioners in providing a consistent level of emotional availability (Bailey et al, 2013; Virmani and Ontai, 2010) In particular, interventions with ECEC practitioners which emphasises mindfulness training appear to boost their 'psychological flexibility' (Biglan, et al, 2013) whilst improving the behaviour of children themselves (Singh et al, 2013). These 
Geoff Taggart (C)

interventions need careful handling since they involve exposing the 'shadowside of virtue' (Flax, 1993) and revealing the 'existence of conflict, aggression, ambivalence and discord in feelings and experiences related to care'(Sevenhuisjen, 2004:13).

Finally, there are implications for the nursery as a compassionate organisation which attends to both 'care' and 'rights'. Certainly, it may be beneficial for the nursery to be a 'reflective space' (Leverett and Rixon, 2011) and a space for democratic practice (Oliveira-Formosinho and Araujo, 2011) in which respect for diversity of all kinds may flourish. But for this ideal to be embedded, the setting needs to be emotionally safe. Geddes (2006) suggests that a school/setting needs to act as a 'secure base' for staff as well as children: perhaps in an early years context this can be provided by group supervision (Soni, 2013; Brody and Friedman, 2012). A significant amount of research has been conducted by Elfer into the emotional context of nursery work and the implications for practitioners (e.g. Elfer, 2013; Elfer, 2012; Elfer 2006; Page and Elfer, 2013; Elfer and Dearnley, 2007). A central recommendation of his work is that supervision should be taken seriously within settings, perhaps following a psychoanalytic model of 'work discussion' (Elfer, 2012). This may help alleviate the growing incidence of burnout in early childhood staff (e.g Noble and Macfarlane, 2005) and is particularly urgent, bearing in mind, for example, that the tendency for compassion is both easily overridden by stress (Gilbert, 2009) and that this stress also seems to predict lower quality care-taking behaviour (deSchipper et al, 2009).

Setting managers are now able to draw on accumulating evidence from research into compassion within organisations more generally (e.g. Dutton et al, 2014), blending this with their own philosophies: the Te Whariki approach, for example, incorporates aroha (compassion) as one of its key principles. Wang $(2005: 111)$ points out that the tool for realising a compassionate culture is compassion itself which 'facilitates the ability to co-create states that are safe and allows us to move out of the self-protective and self-preservative systems'. 
Geoff Taggart (C)

Nurturing this principle means allowing practitioners to reflect and experiment and allowing leaders to be fully available to children, parents and staff. As Hugman (2005:61) remarks, 'it is the social relations between service users and professionals that reveal the ethics of compassion.'

\section{Conclusion: a compassionate paradigm for ECEC}

Because of our cultural history, it is difficult for us nowadays to have 'moral emotions' for children which are not seen as sentimental or ethically dubious. Such is the dominance of duty-based ethics, feelings for children in our care may be regarded as instinctive, natural and understandable but rarely as morally intelligent. Yet one should remember that, along with Kant, other contemporary philosophers (e.g. David Hume, Adam Smith) were espousing the ethics of sentiment (feeling), 'universal sympathy' and compassion and, if the Enlightenment had not been so patriarchal, these may have had more dominant influence. This paper has sought to show how this attempt to integrate thought and feeling has re-emerged in care ethics and compassion research, with implications for how we understand the work that early childhood teachers do. As it becomes increasingly clear that the modernist mindset no longer serves us, compassionate pedagogy allows us to draw upon this new paradigm in training future practitioners without falling into pity and sentimentality. For example, when a graduate from a programme in compassionate pedagogy acknowledges her own nervousness in meeting a new parent, she does not need sentimentality or pity, only understanding. In a nursery serving an area of deprivation, she warmly welcomes the mother and child into a side room. She is not thinking of the training on 'customer care' demanded by the nursery chain. She simply responds with smiles and animated interest to the child's questions whilst appreciating the courage of the mother to enter somewhere unfamiliar and strange. An open discussion can then start. In such critical pedagogy, this emotion of compassion is key to ethical practice. 
Geoff Taggart (C)

4892 words (including English abstract)

\section{References}

Armstrong, K. (2011) Twelve Steps to a Compassionate Life London: Bodley Head

Bai, H. (2014) Editorial introduction to special themed issue: Working compassion Paideusis: the Journal of the Canadian Philosophy of Education Society 21 (2): 2-4

Bailey, C.S., Zinsser, K.M., Curby, T.W., Denham, S.A. and Bassett, H.H. (2013) Consistently emotionally supportive preschool teachers and children's social-emotional learning in the classroom: implications for center directors and teachers NHSA Dialog 16 (2): 131-137

Biglan, A., Layton, G.L., Jones, L.B., Hankins, M. and Rusby, J.C. (2013) The value of workshops on psychological flexibility for early childhood special education staff Topics in Early Childhood Special Education 32 (4): 196-210

Boyer, K., Reimer, S. and Irvine, L. (2012) The nursery workspace, emotional labour and contested understandings of commoditised childcare in the contemporary UK Social and Cultural Geography http://dx.doi.org/10.1080/14649365.2012.710913

Bowlby, J. (1958) The nature of the child's tie to his mother International Journal of PsychoAnalysis 39: 350-373

Brody, D. and Friedman, A. (2012) The effectiveness of community of practice in supporting Israeli kindergarten teachers dealing with an emotionally laden topic, in John A. Sutterby (ed.) Early Education in a Global Context (Advances in Early Education And Day Care, Volume 16) Emerald Group Publishing Limited, pp.183-210

Brown, N.O (1959) Life Against Death: the Psychoanalytic Meaning of History Middletown, CT: Wesleyan University Press

Burman, E. (2007) Deconstructing Developmental Psychology London: Routledge

Burnette, J.L., Taylor, K.W., Worthington, E.L. and Forsyth, D.R. (2007) Attachment and trait forgiveness: the mediating role of angry rumination Personality and Individual Differences 42: 1585-1596

Callaghan, G. and Thompson, P. (2002) "We recruit attitude" : the selection and shaping of routine call centre labour Journal of Management Studies 39 (2) : 233-254

Carr, D. (1999) Professionalism and Ethics in Teaching London: Routledge

Clark, A. and Moss, P. (2011) Listening to Young Children: the Mosaic Approach London: NCB Crowell, J.A. and Feldman, S.S. (1991) Mothers' working models of attachment relationships and mother and child behaviour during separation and reunion Developmental Psychology 27: 597-605 
Dahlberg, G., Moss, P. and Pence, A. (2008) Beyond Quality in Early Childhood Education and Care: Languages of Evaluation London: Routledge

Dalli, C. and Cherrington, S. (2009) Ethical practice as relational work In Edwards, S. and Nuttall, J. (eds.) Professional Learning in Early Childhood Settings Amsterdam: Sense Publishers

Daycare Trust/ TUC (2008) Raising the Bar: what next for the early childhood education and care workforce? London: Daycare Trust

De Schipper, J.C., Tavecchio, L.W.C. and Van Ijzendoorn, M.H. (2008) Children's attachment relationships with day care caregivers: associations with positive caregiving and the child's temperament Social Development 17 (3): $454-470$

Dutton, J.E., Workman, K.M. and Hardin, A.E. (2014) Compassion at work Organisational Psychology and Organisational Behaviour 1: 277-304

Elfer, P. (2006) Exploring children's' expressions of attachment in nursery European Early Childhood Education Research Journal 14 (2): 81-95

Elfer, P. (2012) Emotion in nursery work: Work Discussion as a model of critical professional reflection Early Years 32 (2): 129-141

Elfer, P. (2013) Emotional aspects of nursery policy and practice - progress and prospect European Early Childhood Education Research Journal DOI: 10.1080/1350293X.2013.798464

Elfer, P. and Dearnley, K. (2007) Nurseries and emotional well-being: evaluating an emotionally containing model of professional development Early Years 27 (3): 267-279

Elicker, J., Georgescu, O. and Bartsch, E. (2008) Increasing the sensitivity of childcare providers: applying the video-feedback intervention in a group care setting In Juffer, F., BakermansKranenburg, M.J. and van ljzendoorn, M.H. (eds.) Promoting Positive Parenting: an Attachment-Based Intervention London: Lawrence Erlbaum

Flax, J. (1993) Disputed Subjects: Essays on Psychoanalysis, Politics and Philosophy London: Routledge

Fox, M. (1999) A Spirituality Named Compassion San Francisco: Bear and Co Fournier, V. (1999) The appeal to 'professionalism' as a disciplinary mechanism The Sociological Review 47 (2) :280-307

Fromm, E. (1959) The Sane Society London: Routledge

Geddes, H. (2006) Attachment in the Classroom London: Worth Publishing Ltd Gerhardt, S. (2010) The Selfish Society: How We All Forgot to Love One Another and Made Money Instead London: Simon and Schuster

Gilbert, P. (2009) The Compassionate Mind London: Constable 
Gilbert, P. (2011) Historical, spiritual and evolutionary approaches to suffering, compassion, caring and the caring professions In Gilbert, P. (ed.) Spirituality and Mental Health Brighton: Pavilion

Gillath, O., Shaver, P.R. and Mikulincer, M. (2005) An attachment-theoretical approach to compassion and altruism In Gilbert, P. (ed.) Compassion: its Nature and Use in Psychotherapy London: Routledge

Goetz, J.L. Keltner, D and Simon-Thomas, E. (2010) Compassion: an evolutionary analysis and empirical review Psychological Bulletin 136 (3): 351-374

Goldstein, L.S. and Lake, V.E (2000) 'Love, love and more love for children': exploring preservice teachers' understandings of caring Teaching and Teacher Education 16: 861-872

Gustin, L.W. and Wagner, L. (2012) The butterfly effect of caring - clinical nursing teachers' understanding of self-compassion as a source to compassionate care Scandinavian Journal of Caring Sciences doi: 10.1111/j.1471-6712.2012.01033.x

Held, V. (2007) The Ethics of Care: Personal, Political, Global Oxford: OUP

Hochschild, A. (1986) The Managed Heart: Commercialisation of Human Feeling Berkeley: University of California Press

Hoggett, P., Beedell, P., Jiminez, L., Mayo, M. and Miller, C. (2006) Identity, life history and commitment to welfare Journal of Social Policy 35 (4): 689-704

Hollway, W. and Froggett, L. (2012) Researching In-between Subjective Experience and Reality. Forum Qualitative Sozialforschung / Forum: Qualitative Social Research, [S.I.], v. 13, n. 3 ISSN 1438-5627. Available at: <http://ojs-test.cedis.fu-berlin.de/fqstest/index.php/fqs/article/view/1899/3428>. Date accessed: 26 Aug. 2013

Hugman, R. (2005) New Approaches in Ethics for the Caring Professions London: Palgrave Jazaieri, H., Jinpa, G.T., McGonigal, K., Rosenberg, E.L., Finkelstein, J., Simon-Thomas, E., Cullen, M., Doty, J.R., Gross, J.J. and Goldin, P.R. (2013) Enhancing compassion: a randomized controlled trial of a compassion cultivation training program Journal of Happiness Studies 14 (4): $1113-1126$

Johnson, J. (2010) Positive and Trusting Relationships with Children in Early Years Settings Exeter: Learning Matters

Kunce,L. J. and Shaver, P.R. (1994) An attachment-theoretical approach to caregiving in romantic relationships In Bartholomew, K. and Perlman,D. (eds.) Attachment processes in adulthood Advances in personal relationships London: Jessica Kingsley

Law, V. and Martens, C. (2012) (eds) Don't Leave Your Friends Behind: Concrete Ways to Support Families in Social Justice Movements and Communities Oakland, CA: PM Press

Leverett, S. and Rixon, A. (2011) Reflective spaces In Foley, P. and Leverett, S. (eds.) Children and Young People's Spaces: Developing Practice Maidenhead: OU Press 
Marcuse, H. (1965) One Dimensional Man London: Routledge

Mikulincer, M. and Shaver, P.R. (2005) Mental representations of attachment security: theoretical foundation for a positive social psychology In Baldwin, M.W. (ed.) Interpersonal Cognition NY: Guilford

Mikulincer, M., \& Shaver, P.R. (2001) Attachment theory and intergroup bias: evidence that priming the secure base schema attenuates negative reactions to out-groups Journal of Personality and Social Psychology 81: 97-115

Mikulincer, M., Gillath, O., Sapir-Lavid, Y., Yaakobi, E., Arias, K.,Tal-Aloni, L., \& Bor, G. (2003) Attachment theory and concern for others' welfare: evidence that activation of the sense of secure base promotes endorsement of self-transcendence values Basic and Applied Social Psychology 25: 299-312.

Moss, P. (2003) Getting beyond childcare: reflections on recent policy and future possibilities In Brannen, J. and Moss, P. (eds.) Rethinking Children's Care Maidenhead: OU Press

Narvaez, D. (2008) Triune ethics: the neurobiological roots of our multiple moralities New Ideas in Psychology 26: 95-119

Neff, K. D., \& Germer, C. K. (2013). A pilot study and randomized controlled trial of the mindful self-compassion program. Journal Of Clinical Psychology, 69(1), 28-44

Neff, K. (2003) Self-compassion: an alternative conceptualisation of a healthy attitude toward oneself Self and Identity 2: 85-101

Newman, L. and Pollnitz, L. (2001) Helping students make tough decisions wisely: The challenge of ethical inquiry Australian Journal of Early Childhood 26(4): 39-46

Noble, K. and Macfarlane, K. (2005) Romance or reality? : Examining burnout in early childhood teachers Australian Journal of Early Childhood Vol. 30 No. 3, September 2005, p. 53-58

Noddings, N. (1984) Caring: A Feminine Approach to Ethics and Moral Education Berkeley: University of California Press

Noddings, N. (2010) The Maternal Factor: Two Paths to Morality Berkeley: University of California Press

Nussbaum, M. (2001) Upheavals of Thought: the Intelligence of Emotions Cambridge: CUP Oakley, A. (1974) The Sociology of Housework Oxford: Blackwell

Oliveira-Formosinho, J. and Araujo, S.B. (2011) Early education for diversity: starting from birth European Early Childhood Education Research Journal 19 (2): 223-235

Page, J. and Elfer, P. (2013) The emotional complexity of attachment interactions in nursery European Early Childhood Education Research Journal 
Pascal, C. and Bertram, T. (2009) Listening to young citizens: the struggle to make real a participatory paradigm in research with young children European Early Childhood Education Research Journal 17 (2): 249-262

Penn, H. (2007) Childcare market management: how the United Kingdom Government has reshaped its role in developing early childhood education and care Contemporary Issues in Early Childhood 8 (3): 192-207

Purpel, D. (1989) The Moral and Spiritual Crisis in Education NY: Peter Lang

Rickers, S. (2012) The lived experience of self-compassion in social workers Unpublished PhD University of Minnesota

Robertson, J. and Robertson, J. (1989) Separation and the Very Young London: Free Association Press

Rockliff, H., Karl, A, McEwan, K., Gilbert, J., Matos, M. and Gilbert, P. (2011) Effects of intranasal oxytocin on 'compassion focused imagery Emotion 11(6), p. 1388-96

Rogers, C. (1961) On Becoming a Person London: Constable

Roland, J. (1981) The ideal of the educated person Educational Theory 31 (2): $97-109$

Rose, N. (1999) Governing the Soul: the Shaping of the Private Self [2nd edition] London: Free Association Books

De Schipper, E., Riksen-Walraven, M., Geurts, S. and de Weerth, C. (2009) Cortisol levels of caregivers in child care centers as related to the quality of their caregiving Early Childhood Research Quarterly 24: 55-63

Sevenhuisjen, S. (2004) Citizenship and the Ethics of Care: Feminist Considerations on Justice, Morality and Politics London: Routledge

Simon-Thomas, E.R., Godzik, J., Castle, E., Antonenko, O., Ponz,A., Kogan, A. and Keltner, D.J. (2012) An fMRI study of caring vs self-focus during induced compassion and pride Social Cognitive and Affective Neuroscience 7(6), p. 635-48

Singh, N.N., Lancioni, G.E., Winton, A.S.W., Karazsia, B.T. and Singh, J. (2013) Mindfulness training for teachers changes the behaviour of their preschool students Research in Human Development 10 (3): 211-233

Sörensen, S., Webster, J. D. and Roggman, L.A. (2002) Adult attachment and preparing to provide care for older relatives Attachment and Human Development 4 (1): 84-106

Soni, A. (2013) Group supervision: supporting practitioners in their work with children and families in Children's Centres Early Years: An International Research Journal,33:2, 146-160

Sturdy, A. (1998) Customer care in a consumer society: smiling and sometimes meaning it? Organization 5 (1): 27-53 
Swick, K.J. and Brown, M.H. (1999) The caring ethic in early childhood teacher education Journal of Instructional Psychology 26 (2): 1116-120

Taggart, G. (2011) Don't we care?: the ethics and emotional labour of early years professionalism Early Years 31 (1): 85-95

Tosone, C., Bettmann, J.E., Minami, T and Jasperson, R.A. (2010) New York City social workers after 9/11: their attachment, resiliency, and compassion fatigue International Journal of Emergency Mental Health 12 (2): 103-16

Tronto, J.C. (1993) Moral Boundaries: A Political Argument for an Ethic of Care London: Routledge

Van Galen, J.A. (1996) Caring in community: the limitations of compassion in facilitating diversity In Eaker-Rich, D. and Van Galen, J. (eds.) Caring in an Unjust World: Negotiating Borders and Barriers in Schools Albany, NY: SUNY Press

Virmani, E.A. and Ontai, L.L. (2010) Supervision and training in childcare: does reflective supervision foster caregiver insightfulness? Infant Mental Health Journal 31 (1): 16-32

Walkerdine, V., Lucey, H. and Melody, J. (2001) Growing Up Girl: Psycho-social Explorations of Gender and Class London: Palgrave

Wang, S. (2005) A conceptual framework for integrating research related to the physiology of compassion and the wisdom of Buddhist teachings In Gilbert, P. (ed.) Compassion:

Conceptualisations, Research and Use in Psychotherapy London: Routledge

Weng, H., Fox, A.S. ,Shackman, A.J., Stodola, D.E., Caldwell, J.Z. K., Olson, M.C.,. Rogers, G.M. and Davidson, R.J. (2013) Compassion training alters altruism and neural responses to suffering Psychological Science, 0956797612469537,

Ying, Y. (2009) Contribution of self-compassion to competence and mental health in social work students Journal of Social Work Education 45 (2): 309-323 